\title{
The Effects of Perceived Satisfaction Level of High-Involvement Product Choice Attribute of Millennial Generation on Repurchase Intention: Moderating Effect of Gender Difference*
}

\author{
Young Ei KIM ${ }^{1}$, Hoe Chang YANG ${ }^{2}$ \\ Received: September 13, 2019 Revised: November 01, 2019 Accepted: November 15, 2019
}

\begin{abstract}
The purpose of this study is to derive various clues for the establishment of marketing strategies for companies that produce and sell high-involvement products for Millennials who are not the subject of current consumption but who will lead future consumption. For this purpose, this study aimed to derive 17 factors of high-involvement product selection attributes through FGI, and its relationship on repurchase intention after make a variable through PCA. A total of 158 valid questionnaires were used, and IPA, independent sample t-test, regression analysis, and hierarchical controlled regression analysis were performed. The results showed that overall, external and internal selection factors had a positive influence on repurchase intentions, and in particular, appealing to internal and external selection factors in order to promote repurchase intention. Meanwhile, the Millennials were found to have no gender difference. Therefore, the company producing and selling high-involvement products suggests that it is necessary to make a priority effort to secure brand awareness, trust in product producers, store trust, and product self-reputation as components of internal selection factors. It was also concluded that more strategic efforts were needed to focus on and appeal to the characteristics of the Millennial itself rather than to consider gender differences.
\end{abstract}

Keywords : Millennial Generation, High-Involvement Product Choice Attribute, Repurchase Intention, Gender Difference

JEL Classification Code : L10, L15, M10, M12, M31

\section{Introduction}

The main section of an article should start with an introductory section which provides more details about the paper's purposes, motivation, research methods, and

\footnotetext{
* This paper was presented initially at 2019 International Conference on Business and Economics (ICBE2019) and the 15th International Conference of KODISA that was held in Yeosu, South Korea. Reviewed by new discussion of two panelists and revised faithfully reflected by three anonymous reviewers.

1 First Author, Professor, Department of Business Administration, Seoul Digital University, Republic of Korea. Email: kimyei@naver.com

2 Corresponding Author, Assistant Professor, Dept. of Distribution Management, Jangan University, Korea. [Postal Address: 1182 Samcheonbyeongma-ro, Bongdam-eup, Hwaseong-si, Gyeonggido, 18331, Korea] Email: pricezzang@naver.com

(c) Copyright: Korean Distribution Science Association (KODISA)

This is an Open Access article distributed under the terms of the Creative Commons Attribution Non-Commercial License (http://Creativecommons.org/licenses/by-nc/4.0/) which permits unrestricted noncommercial use, distribution, and reproduction in any medium, provided the original work is properly cited.
}

findings. The introduction should be relatively nontechnical, yet clear enough for an informed reader to understand the manuscript's contribution. It is true that the consumption tendency of traditional consumers was easily predicted because of their limited range of consumption. For example, VIP marketing or Prestige marketing, one of the typical traditional strategies of companies, was based on Pareto's claim that a small proportion of distributors owned most of the wealth. Therefore, it is known that companies can use effective marketing strategies that applies for most of the consumers. Their performance has been considerable even if the division of disposable income between sexes, age, social status or economic point of view is taken into account. From this point of view, it can be easily predicted that demand will be concentrated in the ultra-high or low-end of the market due to the polarization of income when considering the ongoing economic recession in Korea.

However, it is a fact that the consumers' consumption tendency has changed in many ways. For example, in the case of the middle class, which is the mainstay of massive 
marketing that led to the popularization of luxury goods, there is a double consumption style that considers bidding expenditure for oneself consume but also considers the price aspect as well when using an online distribution channel. It has also become possible to interpret men's active purchasing behaviors in relation to beauty care products and programs such as cosmetics, which was an area formerly reserved for women. Thus, this current study focuses on the consumption tendency of this generation, the millennial generation. According to Kertzer (1983), generations include people belonging to a generation within a family, born in a similar period, and people in the same phase of a human life cycle. The Millennial generation in this study is also known as the $\mathrm{Y}$ or $\mathrm{Z}$ generation, but domestic and foreign researchers (Howe \& Strauss, 2009; Lee, Kwahk, Han, Jeing, Park, Kim et al., 2017) consider the Millennial generation to those born between the 1980s to early 2000 .

The reason why the Millennial generation is the focus of this study is because of their distinct characteristics compared to the former generations and also their prominent role in future consumer markets (Culiberg \& Mihelič, 2016; Deloitte, 2014). Oh, Kwon and Lee. (2014) has suggested that the Millennial generation is capable of multitasking, has high self-esteem, and better abilities to utilize technology as well as enhanced levels of social awareness. In addition to having a variety of devices compared to other generations at their disposal (Lee \& Engelman, 2012; Zickuhr, 2011), they are able to better utilize the functions provided by such devices (Frosini \& Paternò, 2014), and utilize them easily even in their first time (Eubanks, 2006). Moreover, rather than purchasing high-priced electronic products, they are more open and inclined to sharing such products with each other. This is in line with implications that these generations tend to pursue more of the practicality and rationality of the products rather than the brand names (Garikapati, Pendyala, Morris, Mokhtarian, \& McDonald, 2016).

Therefore, the purpose of this study is to present the various clues needed to establish marketing strategies for millennial households, who will be the majority of the consumer market in the near future. The following approach was applied in this research. First, the prediction in consumption propensity of the Millennial generation was confirmed by assessing the importance and satisfaction level of the optional attributes related to purchasing high involvement products in the Millennial generation. Second, the effect of the degree of satisfaction on high - involvement product selection attributes of the Millennial generations on repurchase intentions were also examined. Third, by verifying the moderating effects of gender differences that were used to classify the traditional consumption patterns, whether or not the role and its applications in the traditional gender classification scheme applied to STP (Segmentation, Targeting and Positioning) could also be applied to the Millennial generation was observed. This study will be an opportunity to present a fresh perspective on recognizing the change from the existing generation to the future millennial generation in terms of consumer marketing, and it is expected that the companies that are engaged in the production and sales of high involvement products and the marketing companies will be able to attain many implications from such observations.

\section{Literature Review}

\subsection{Millennial Generation}

A generation can be divided into groups with a common historical and social identity (Solomon \& Rabolt, 2004) as well as populations born at the same time in terms of biology. This also includes the inherent collective memory established in adolescence in the same generation (Schuman $\&$ Scott, 1989). The Millennial generation (or Y generation) that is of interest in this study is classified as those being born in 1985 to early 2000 (Cogin, 2012; Crumpacker \& Crumpacker, 2007; Straus \& Howe, 1991). Looking at previous studies of Millennials, they underestimated traditionally high-value factors such as marriage, child planning, and home ownership (Nielsen, 2015; Taylor \& Keeter, 2010), good at collaboration (Howe \& Strauss, 2009; Myers \& Sadaghiani, 2010), but they have a strong individualistic tendency ( $\mathrm{Ng}$ et al., 2010), a high rate of turnover intentions (Nielsen, 2015) and a relatively optimistic attitude toward the future (Howe \& Strauss, 2009; Stafford \& Griffis, 2008; Lee et al., 2017).

\subsection{Highly Involvement Product Choice Attributes}

Involvement is a factor that affects consumers' purchasing decisions or purchasing behaviors and it includes the individual's psychological status such as personal importance, interest level, and motivation level as well as the degree of consumer involvement is divided according to product, consumer, and situational characteristics (Yoon, Kim, \& Oh, 2012). On the other hand, in terms of marketing, involvement is the degree to which the content of the stimulus provided to oneself is related to the content of one's life (Krugman, 1965), and it is defined as the general level of interest in the subject (Day, 1970). Many studies (Antil, 1984; Assel, 1984; Engle \& Blackwell, 1982; Robertson, 1976; Traylor, 1981) categorized the involvement of consumers into high involvement and low involvement.

Product selection attributes can be classified into intrinsic attributes that are classified by product quality itself, and external attributes such as price and brand, both of which play an important role in affecting the importance and satisfaction with the consumers' purchase intentions (Zeithaml, 1988). Consumers prefer to use a unique measure or a regularly used selection criterion to evaluate the product and to prioritize it (Stanley \& Sewall, 1976). Therefore, the high-involvement product selection attributes that are of interest in this study are not only highly perceived by 
consumers but also have a high degree of interest and are of a complex nature such as high price and strong brand loyalty and preference (Engle \& Blackwell, 1982; Traylor, 1981). The priorities of the products are dependent on the intrinsic level of each consumers' selection criterion (Stanley \& Sewall, 1976; Zeithaml, 1988).

\subsection{Repurchase Intention}

Repurchase intention is an individual's belief (Ahn, Myeong, \& Yoon, 2014) that they want to purchase and use a product or service, evaluate it, and then form a specific attitude and express repurchase behavior. Therefore, the repurchase intention is an intention to continuously use the products or services currently used by consumers. The repurchase intention can be summed as the possibility that the consumer repeatedly purchases the product with his or her beliefs that he / she repeatedly purchases by evaluating the purchase experience (Ryu \& Lee, 2013).

The reason for adopting repurchase intention in this study is that the repurchase intention was found to have a significant relationship with customer satisfaction as a result of reviewing previous studies. For example, not only studies showing that customer satisfaction affects future purchase intentions (Choi, Lee, \& Yang, 2014; Tam, 2004; Yang \& Cho, 2018), Other studies (e.g. Choi, 2010; Kim \& Lee, 2017; Mcdougall \& Levesque, 2000; Sivadas \& Baker-Prewitt, 2000) show that they are willing to repurchase if they are satisfied with the high-involvement choice attributes.

\subsection{Gender Difference}

Gender differences can be classified into either biological or social concepts. According to Hong, Kim, Kim, Kim, Park, Park et al. (1998), there are gender differences in biological characteristics such as differences in sexes, chromosomes, and differences in the brain such as intelligence, spatial and temporal abilities. Additionally, different ways of behaving between the genders can affect each individuals' ability and their likability evaluation (Buss, 1988; Buss \& Kenrick, 1998; Eagly \& Wood, 1997; Powers \& Zuroff, 1988; Rudman, 1998). There was also shown to be differences between the genders in purchasing decisions (Chun \& Jung, 2006; Lee, 2008; Park, 2010).

\section{Research Methods, Materials and Research Design}

\subsection{Research Methods and Materials}

A total of 157 valid questionnaires were used for the analysis by using the self - report questionnaire for the first and second years of $\mathbf{J}$ university students. Respondents were given an additional 5-points as previously informed. The respondents were 102 males $(65.0 \%)$ and 55 females $(35.0 \%)$, and the mean age was 19.67 years (standard deviation 1.624).

The measurement scale is as follows. The selection of high-involvement products is based on previous studies (e.g. Park, Kim, \& Yang, 2015; Yang, Kwon, \& Kim, 2014; Yang, Choi, Lee, \& Kim, 2016; Yang, Cho, \& Kim, 2017). We adopted Yang, Hur and Yang (2018)'s proven strategic approach and attempted to derive it through Focus Group Interview (FGI) which is one of the qualitative research methods. To this end, we reviewed previous studies and conducted a target group interview with three experts with a Ph.D. degree in marketing to derive a total of 17 selection attribute factors for laptops with the most purchasing experience among college students (17 choice attributes are shown in <Table 1>). Repurchase intention was measured four items such as "I want to purchase this product again" on a Likert 5-point scale based on a study by Anderson, Fornell and Lehmann (1994).

\subsection{Research Design}

Shin and Lee (2018) pointed out that the Millennial generation is self-centered and individualistic. Therefore, they showed self-oriented consumption tendencies based on narcissism and the also consumption tendencies based on what others thought of them as well (Shin \& Lee, 2018). For the reason behind the self-oriented consumption tendency of the Millennium era, it is thought that the millennial generation had grown up receiving praises from their parents, who are the baby boomers, and thus came to assume that they deserved special treatment as a result of such upbringing (Lancaster \& Stillman, 2010). In recent years, with the decreased rate of the global economic state, the Millennials have become worried about their unstable future, and it is thought that this is the reason why they have become more focused on their present happiness rather than their future (Shin \& Lee, 2018). Not only this, but the Millennial generation is also affected by both the reference group and the overabundance of choices, resulting in indecision and propensity for being more conscious about others around them (Shin \& Lee, 2018).

Engel and Blackwell (1982) presented a generalized decision making process model that includes all the processes of problem recognition, information search, alternative evaluation, purchase decision, and post purchase decision. In this process, the degree of satisfaction from the use of the product increases the intention of purchasing the product, so that the consumer purchases the product they normally chose in the past. If the satisfaction of the purchased product is consistent, it becomes a repurchase decision. The decision-making process can be interpreted in the same context as presented in the Consumer Decision Journey Model of the Mckinsey \& Company report (van Bommel, Edelman, \& Hngerman, 2014). In other words, if the purchasing experience of a high-involvement product is evaluated as positive, it may have a positive effect on the repurchase intention as well. Thus, if the satisfaction of the products is high, then it is very likely that the consumer will 
not go through the normal steps of investigating information about the different products, but proceed to the repurchase decision. With this in mind, the following hypothesis was established in this study.

Hypothesis 1: The satisfaction level of high-involvement product choice attributes perceived by Millennials will have a positive (+) effect on repurchase intention.

The <Hypothesis $1>$ is classified into four factors as a result of Principle Component Analysis (PCA) on the selection attributes presented below, but the fourth factor was not used in the analysis (see Table 1). Therefore, the sub-hypotheses of <Hypothesis 1>, which are named as three factors, overall selection, external (performance), and internal(trust), are as follows.

Hypotheses 1-1: The degree of satisfaction with the overall selection factor among high- involvement product selection attributes perceived by the Millennial generation will have a positive (+) effect on the repurchase intention.

Hypothesis 1-2: Among the high-involvement product selection attributes perceived by Millennial generations, satisfaction with external factors will have a positive effect on repurchase intentions.

Hypothesis 1-3: Among the high involvement product selection attributes perceived by Millennial generations, satisfaction with internal factors will have a positive effect on repurchase intention.

Traditionally, gender differences have been reported to be present in various aspects (Buss, 1988; Buss \& Kenrick, 1998; Eagly \& Wood, 1997; Powers \& Zuroff, 1988; Rudman, 1998). According to the study of purchasing, there are differences in the products purchased due to differences in the value given to material ownership and the decisionmaking process of purchasing (Peter \& Olson, 1999). There is also a claim in the studies that women are more likely to make unplanned purchases than men (Rook \& Hock, 1985), but that there is no difference in terms of maintaining the same purchase frequency (Kollat \& Willett, 1967). There are also studies in which men are more likely show impulsive buying behavior compared to women (Cobb \& Hoyer, 1986; Mai, Jung, Kantz, \& Loeb, 2003). For this reason, Iacobucci and Ostrom (1993) showed that for the males, they assessed the aspects of the services provided itself by comparing the service itself and whether or not it was able to satisfy what their intended goal was as well.

For the females, it was observed that they placed more emphasis on the relational factors between themselves and the service that was provided. In terms of judgment and behavior, it could be seen that male tended to be goaloriented, while the women tended towards relationaloriented behavior, revealing the gender factors that also played into consumer behavior (Eagly, 1987). This prominent differences between the genders was also the reason why there has been traditional assumptions on the differences of gender roles in terms of consumption (Meyers-Levy, 1989). If these claims could be applied to the Millennial generation as well, then this demonstrates the common ground with the past generations, and it can be inferred that the traditional gender roles in relations to marketing strategies can be kept in place as well. However, considering that the gap between men and women has been decreasing in many parts of the modern era, it is not possible to exclude the possibility that the millennial generation will be different from the past generations. Thus, in this study, the following hypothesis was established by also incorporating the traditional viewpoint as well.

Hypothesis 2: Gender differences between highinvolvement product choice attributes and repurchase intentions perceived by Millennial generations will be moderated.

Hypothesis 2-1: Gender differences between the general selection factors and the repurchase intentions of the high involvement product selection attributes perceived by the Millennial generation will be moderated.

Hypothesis 2-2: Among the high-involvement product selection attributes perceived by Millennial generations, gender differences between external factors and repurchase intentions will be moderated.

Hypothesis 2-3: Gender differences between intrinsic factors and repurchase intentions among high involvement product selection attributes perceived by Millennial generations will be moderated.

The structured research model reflecting the above hypotheses is presented in <Figure 1>.

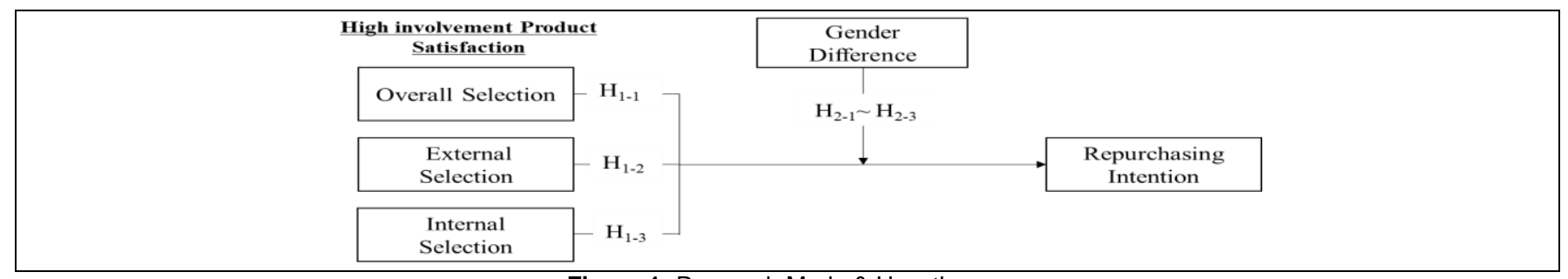

Figure 1: Research Mode \& Hypotheses 


\section{Results and Discussion}

\subsection{Results of PCA (Principal Component Analysis) on Product Attributes}

The satisfaction level of the 17 high-involvement product choice attributes adopted in this study was divided into four factors. The first factor was divided into five items such as product completeness, quality excellence, functional convenience, product reliability, and environmental reputation. This was called the 'overall selection factors' and defined as the overall choice for high involvement products that Millennials evaluate through experience. The second factor was divided into five items such as hardware, performance, software, design, and price, which were name as 'external selection factors'. The third factor was brand awareness, corporate trust, store trust, and product reputation, which were named as 'internal selection factors'. Finally, the four factors were classified into three items of durability, A/S support, and scarcity, but the relationship between the items was not clear, so we named them as 'product' and excluded them from the analysis.

The Kaiser-Meyer-Mlkin (KMO) measurement was shown to be 0.837 in this study, And Bartlett's test of sphericity $\left(\chi^{2}=1.059 .155\right.$, d.f $\left.=136, p=.000\right)$ was also used to confirm the suitability of the model.

Table 1: Resuts of PCA

\begin{tabular}{|c|c|c|c|c|c|}
\hline Naming & Item & Factor 1 & Factor 2 & Factor 3 & Factor 4 \\
\hline \multirow{5}{*}{ Overall Selection } & product completeness & 0.777 & 0.253 & 0.120 & 0.096 \\
\hline & quality excellence & 0.737 & 0.347 & -0.015 & 0.281 \\
\hline & functional convenience & 0.673 & 0.229 & 0.272 & -0.011 \\
\hline & product reliability & 0.628 & 0.073 & 0.365 & 0.237 \\
\hline & reputation & 0.589 & 0.124 & 0.484 & -0.071 \\
\hline \multirow{3}{*}{$\begin{array}{l}\text { External } \\
\text { Selection }\end{array}$} & hardware & 0.241 & 0.853 & 0.038 & 0.105 \\
\hline & design & 0.025 & 0.581 & 0.460 & -0.147 \\
\hline & price & 0.048 & 0.498 & 0.063 & 0.318 \\
\hline \multirow{3}{*}{$\begin{array}{l}\text { Internal } \\
\text { Selection }\end{array}$} & brand awareness & 0.179 & 0.004 & 0.786 & -0.060 \\
\hline & production company trust & 0.209 & 0.121 & 0.708 & 0.268 \\
\hline & sales store trust & 0.104 & 0.106 & 0.638 & 0.365 \\
\hline
\end{tabular}

\subsection{Reliability and Validity Analysis}

As a result of confirmatory factor analysis to confirm the convergence validity of each item, standard estimates of the scarcity of product factors and design, price of external choice factors were found to be less than 0.5 , so we eliminated these items and the confirmatory factor analysis was assessed again. To confirm the internal consistency, the results of reliability analysis using Cronbach's $\alpha$ coefficient are presented in <Table 2>.

As could be observed in <Table 2>, the results of the confirmatory factor analysis using the remaining items of the fourth factor showed that the construct reliability was 0.602. The AVE was 0.431, and Cronbach's $\alpha$ coefficient was also 0.562 , which was not enough to ensure reliability and was not used in the analysis because it was not considered to be related to the two items.
Table 2: Resuts of Reliability and Validity

\begin{tabular}{|c|c|c|c|c|}
\hline Variable & $\begin{array}{c}\text { Final } \\
\text { Item }\end{array}$ & $\begin{array}{c}\text { Construct } \\
\text { Reliability }\end{array}$ & AVE & $\begin{array}{c}\text { Cronbach's } \\
\boldsymbol{\alpha}\end{array}$ \\
\hline $\begin{array}{c}\text { Overall } \\
\text { Selection }\end{array}$ & 5 & 0.863 & 0.558 & 0.825 \\
\hline $\begin{array}{c}\text { External } \\
\text { Selection }\end{array}$ & 3 & 0.875 & 0.702 & 0.840 \\
\hline $\begin{array}{c}\text { Internal } \\
\text { Selection }\end{array}$ & 4 & 0.822 & 0.539 & 0.773 \\
\hline Product & 2 & 0.602 & 0.431 & 0.562 \\
\hline $\begin{array}{c}\text { Repurchase } \\
\text { Intention }\end{array}$ & 4 & 0.842 & 0.584 & 0.845 \\
\hline
\end{tabular}

\subsection{Correlation Analysis}

The results of the correlation analysis to confirm the relationship between the possible causality analysis, discriminant validity and orientation of the variables are presented in <Table $3>$. As a result of the analysis, the correlation coefficients were $0.271 \sim 0.553$, which showed 
positive relationship. It was concluded that the discriminant validity of the squared value of correlation coefficient was compared with the AVE.

Table 3: Resuts of Correlation Analysis (Pearson Correlation, $n=157$ )

\begin{tabular}{|l|c|c|c|c|}
\hline & $\mathbf{1}$ & $\mathbf{2}$ & $\mathbf{3}$ & $\mathbf{4}$ \\
\hline 1. Overall Selection & $(0.558)$ & & & \\
\hline 2. External Selection & $.532^{* *}$ & $(0.702)$ & & \\
\hline 3. Internal Selection & $.553^{* *}$ & $.294^{* *}$ & $(0.539)$ & \\
\hline 4. Repurchase Intention & $.271^{* *}$ & $.284^{* *}$ & $.345^{* *}$ & $(0.584)$ \\
\hline \multicolumn{1}{|c|}{ Mean } & 3.83 & 3.71 & 3.71 & 3.71 \\
\hline S.D & 0.66 & 0.76 & 0.67 & 0.83 \\
\hline
\end{tabular}

Note) ${ }^{* *} p<.01$, AVE marked in ().

\subsection{Results of IPA (Important-Performance Analysis)}

Although not set as a hypothesis, IPA was conducted to confirm the importance and satisfaction level of high involvement product choice attributes of Millennials are as follows. In the first quadrant, product completeness, functional convenience, quality excellence, and product reliability were found to be high among the overall selection factors. This result implies that companies need to develop strategies to maintain and strengthen their laptop products in order for the consumers to continuously purchase these products in the future. In the second quadrant, among the external selection factors, the rarity and the A/S support among the hardware, price, and product factors were distributed. It was observed that the companies needed urgent improvement for these factors. On the other hand, as shown in the third quadrant, respondents' ratings on satisfaction with reputation and scarcity were lower than those on perceived reputation or store, and reliability on products produced in 4 quadrants show that brand awareness is low but satisfaction is high. This result can be interpreted as reflecting the double consumption tendency of the Millennial generations as claimed by Shin and Lee (2018).

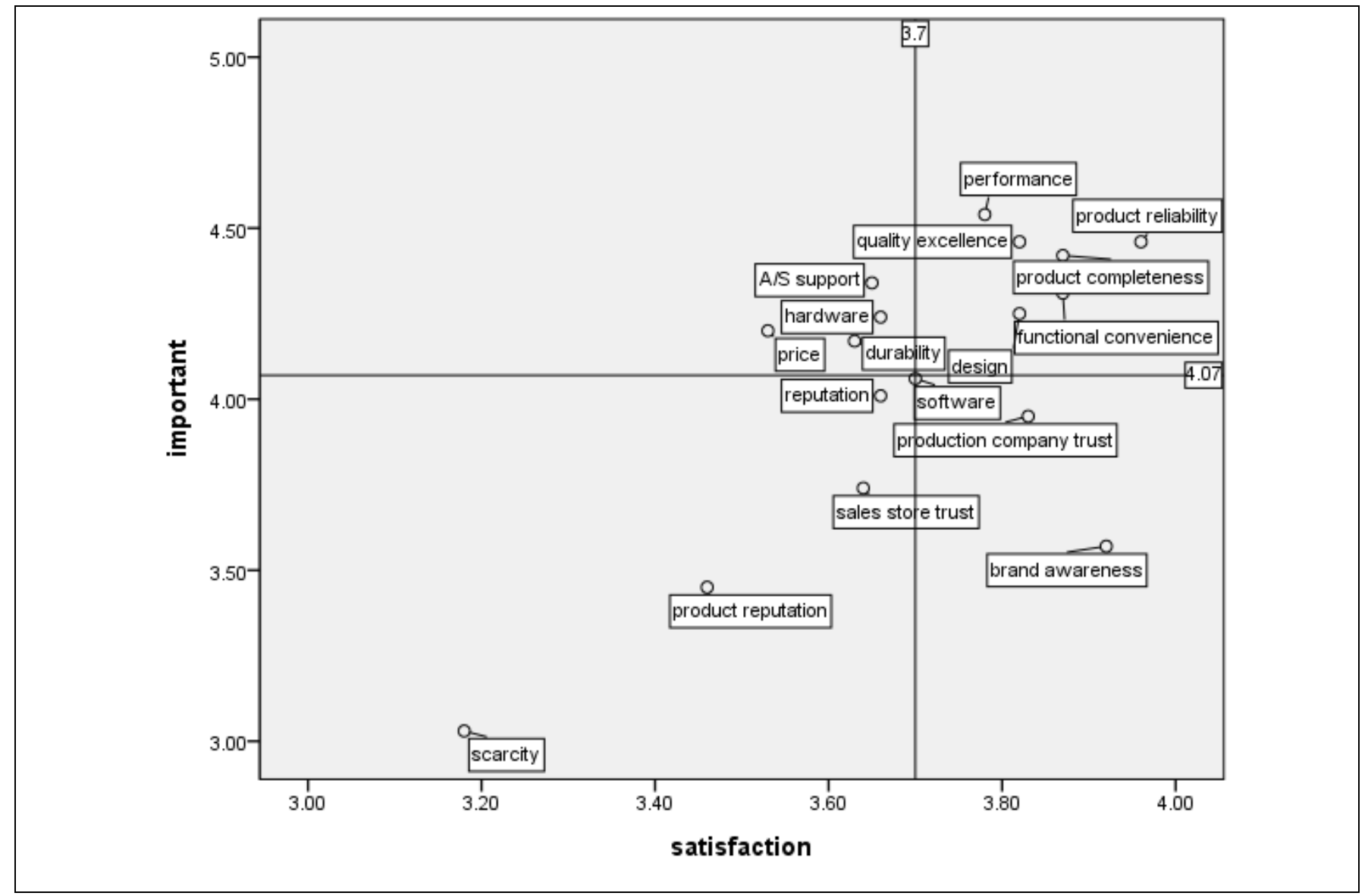

Figure 2: Result of IPA

\subsection{Results of Hypothesis Verification}

Regression analysis was conducted after age control to verify <hypothesis $1>$. The results of this study are as follows. The analysis showed that there was a statistically significant and positively affected between overall selection factors $(\beta=.265, \mathrm{p}<0.01)$, external selection factors $(\beta=.283$, $\mathrm{p}<0.001)$ and internal selection factors $(\beta=.364, p<0.001)$ on repurchasing intention. Therefore, the sub-hypotheses of $<$ Hypothesis 1> were all adopted. 
To analyze which factors had an impact on repurchase intention, the three factors were applied and it showed that the factor of internal selection $(\beta=.305, \mathrm{p}<0.01)$ and external selection $(\beta=.197<0.05)$ had a positive affected, but overall selection factor $(\beta=-.008, \mathrm{p}=0.934)$ had no statistically significant effect on repurchase intention. These results also suggest that the Millennial generations show a double consumption tendency of self-oriented consumption tendency and other-oriented consumption tendency. As a result, companies need to prioritize efforts to secure brand awareness, product manufacturing company trust, store trust, and product self-reputation, which are components of internal selection factors.

To test the <hypothesis 2>, dummy variables were constructed on the basis of male consumers. The independent variables were transformed into z-scores, and then the same ages were regulated and hierarchical regression analysis were performed. The results of this study were as follows: First, the interaction term between the overall selection factor and gender $(\beta=-.201, \mathrm{p}=0.135)$, the factor of interaction term between external selection factor and gender $(\beta=-.181, p=0.172)$, and the factor of interaction term between internal selection factor and gender $(\beta=-.076, \mathrm{p}=.539)$ were not statistically significant, respectively. Therefore, all of the hypotheses in <Hypothesis $2>$ were rejected. This result can be interpreted that there is no gender difference in the Millennial generation compared to the previous generations. The results of the independent sample t-test are not shown in Table. The research showed that the process of confirming the gender difference for each factor of the high involvement product selection attribute can provide more clues to be considered at the enterprise level. It can be observed that the 17 factors were all statistically insignificant. Therefore, companies that produce and sell high-involvement products suggest that more strategic efforts will be needed to pay attention to the characteristics of the Millennial generation itself than to consider gender differences.

\section{Conclusions}

The purpose of this study was to identify the factors that are needed to focus more on the factors that produce and sell high involvement products for the Millennial generation that will lead the future consumption. It was also elucidated on identifying the various clues that were necessary to establish the marketing strategies for the companies.

The following conclusions and implications can be drawn from this study. First, as suggested by Shin and Lee (2018) through IPA, the Millennial generations showed that they are not self-directed, but also have a dual propensity toward consumption. In addition, the IPA result should establish strategies to maintain and strengthen performance and design among the overall selection factors of companies, such as product completeness, functional convenience, quality excellence, product reliability and external selection factors. Among the external selection factors, it was shown that urgent improvement was needed for scarcity of the product as well as A/S support among the product factors. Second, it was found that overall selection factor, external selection factor, and internal selection factor have a positive effect on repurchase intention, and in particular, internal choice factor and external choice factor can promote repurchase intention. These results also reflect the dual consumption patterns of the Millennial generations. Therefore, for companies that produce and sell highinvolvement products, it is necessary to prioritize efforts to secure brand awareness, product manufacturing company trust, and store trust, and product self-reputation, which is a component of internal selection factors. This suggests the need for a strategy for improvement. Third, it was confirmed that there is no gender difference in the high - involvement product selection attribute and its sub - factors in the Millennial generation. This result can be interpreted that the male and female sex differences, which were generally accepted by previous generations, do not apply to the millennial generation. Therefore, companies that produce and sell high-involvement products suggest that more strategic efforts will be needed to pay attention to the characteristics of the Millennial generation itself rather than to consider gender differences.

Despite the many implications of this study for the satisfaction of the high involvement product selection attributes of the millennial generations, there are some limitations that need to be reflected in future studies. First, respondents in this study do not have the ability to purchase high involvement products. Although the questionnaire suggests a situation in which parents express their opinions when purchasing, the presence or absence of purchasing power can have a considerable influence on determining the importance or satisfaction of the optional attribute. Therefore, in future studies, it is necessary to control the purchasing power of Millennials born in the early 1980s and early 1990s by adding samples and analyzing them through additional questionnaires. Second, the limitation of comparing the sex differences of the Millennial generation is limited. As Iacobucci and Ostrom (1993) demonstrates, in the case of male consumers, they are oriented towards the assessment of the essential aspects and achievement of goal levels, so the product or the service itself is unlikely to have a significant impact. On the other hand, female consumers consider the factors of relationships more than their male counterparts, so the products and the service are more likely to have an impact. Thus, with the considerations for these different aspects of gender, future studies might be able to reflect not only on the product or the service itself, but also on aspects such as the environment and other various factors for the assessment of the Millennial consumers. This is because the Millennial generation is from those between the 1980s to the early 2000s, but the $\mathrm{Z}$ generation is from after 1995, which could demonstrate different consumption tendencies. Therefore, it is expected that future research will also provide various clues to companies related to these future consumers. 


\section{References}

Ahn, S. H., Myeong, S. H., \& Yoon, D. I. (2014). The effects of emotional value of consumption of coffee shop users on their consumption propensities and customer behavioral intentions. Journal of Tourism Sciences, 38(8), 271-293.

Anderson, E. W., Fornell, C., \& Lehmann, D. R. (1994). Customer satisfaction, market share, and profitability: Findings from Sweden. Journal of Marketing, 58(3), 5366.

Antil, J. H. (1984). Conceptualization and operationalization of involvement. Advances in Consumer Research, 11, 203-209.

Assael, H. (1984). Consumer behavior and marketing action (2nd, ed.), Boston: Kent Publishing Company.

Buss, D. M. (1988). The evolution of human intra-sexual competition: Tactics of mate attraction. Journal of Personality and Social Psychology, 54(4), 616-628.

Buss, D. M., \& Kenrick, D. T. (1998). Evolutionary social psychology. In D. T. Gilbert, S. T., Fiske, \& G. Lindzey (Eds.), Handbook of social psychology (4th Ed., Vol. 2, pp.982 -1026). Boston: McGraw-Hill.

Cobb, C. J., \& Hoyer, W. D. (1986). Planned versus impulse purchases behavior. Journal of Retailing, 62(4), 384-409.

Choi, B. N., Lee, H. H., \& Yang, H. C. (2014). Impacts of value inclination and self-expressive consuming propensity upon eco-friendly product purchasing intention. East Asian Journal of Business Management, 4(4), 39-49.

Choi, J. H. (2010). The effects of social commerce attributes on the satisfaction and repurchasing intention for a college women student according to restaurant and food choices. The Korean Journal of Food and Nutrition, 27(1), 19-39.

Chun, W. Y., \& Jung, H. J. (2006). Effects of online reviews on evaluation and purchase intention of a product in internet shopping: The role of gender differences. Korean Journal of Consumer and Advertising Psychology, 7(1), 113-129.

Cogin, J. (2012). Are generational differences in work values fact or fiction? Multi-country evidence and implications. The International Journal of Human Resource Management, 23(11), 2268-2294.

Crumpacker, M., \& Crumpacker, J. M. (2007). Succession planning and generational stereotypes: Should HR consider age-based values and attitudes a relevant factor or a passing fad? Public Personnel Management, 36(4), 349-369.

Culiberg, B., \& Mihelič, K. K. (2016). Three ethical frames of reference: Insights into millennials' ethical judgements and intentions in the workplace. Business Ethics: A European Review, 25(1), 94-111.

Day, G. S. (1970). Buyer attitude and brand choice. New York: Free Press.

Deloitte (2014). Big demands and high expectations. The Deloitte millennial survey. Retrieved September 4, 2017 from

www2.deloitte.com/content/dam/Deloitte/global/Docum ents/About-Deloitte/gx-dttl-

2014- millennial-survey-report.pdf.

Eagly, A. H. (1987). Sex differences in social behavior: A social-role interpretation. Hillsdale, NJ: Erlbaum.

Eagly, A. H., \& Wood, W. (1999). The origins of sex differences in human behavior: Evolved dispositions versus social roles. American Psychologist, 54(6), 408423.

Engel, J. F., \& Blackwell, R. D. (1982). Consumer behavior (4th ed.). New York: Dryden Press.

Eubanks, S. (2006). Millennials: Themes in current literature (Ed.). Azusa, CA: Azusa Pacific.

Frosini, L., \& Paternò, F. (2014). User interface distribution in multi-device and multi-user environments with dynamically migrating engines. In Proceedings of the 2014 ACM

SIGCHI symposium on Engineering interactive computing systems, ACM, 55-64.

Garikapati, V. M., Pendyala, R. M., Morris, E. A., Mokhtarian, P. L., \& McDonald, N. (2016). Activity patterns, time use, and travel of millennials: A generation in transition? Transport Reviews, 36(5), 558-584.

Hong, S. J., Kim, M. J., Kim, A, Y., Kim, H. H., Park, Y. S., Park, Y. S., Bang, H. J., Lee, S. J., Lee, O. H., Lee, J. Y., Chun, Y, H., Cho, S. H., \& Cho, H. J. (1998). Women's psychology: Psychological understanding of women. Seoul: Education Science Co.

Howard, J. A., \& Sheth, J. N. (1969). The theory of buyer behavior, New York: John Wiley.

Howe, N., \& Strauss, W. (2009). Millennials rising: The next great generation. New York: Vintage (Knopf Doubleday Publishing).

Iacobucci, D., \& Ostrom, A. (1993). Gender differences in the impact of core and relational aspects of services on the evaluation of service encounters. Journal of Consumer Psychology, 2(3), 257-286.

Kertzer, D. (1983). Generation as a sociological problem. Annual Review of Sociology, 9(August), 125-149.

Kim, G. Y., \& Lee, W. J. (2017). A study on the influence of social media (SNS) content type of corporate marketing to user purchase intention: Focusing on the mediating effect of satisfaction and the moderating effect of individual characteristics. Asia-Pacific Journal of Business Venturing and Entrepreneurship, 12(3), 75-86.

Kollat, D. T., \& Willet, R. P. (1967). Consumer impulse purchase behavior. Journal of Marketing Research, 1(Feb), 21-31. https://doi.org/10.1177/002224376700400102

Krugman, H. E. (1965). The impact of television advertising: Learning without involvement, Public Opinion Quarterly, 29(3), 349-356.

Lancaster, L., \& Stillman, D. (2010). The M-Factor, Delta Sky Magazine. Retrieved May 10, 2019 from https://tantor-marketingassets.s3.amazonaws.com/sellsheets/1667_Mfactor.pdf 
Lee, D., \& Engelman, K. (2012), The impact of mobile on CPG CRM strategy: A kraft Canada case study. International Journal of Mobile Marketing, 7(1), 5-22.

Lee, M. G., Kwahk, J. Y., Han, S. H., Jeong, D. W., Park, K. D., Kim, J. H., Oh, S. M,. \& Chae, G. H. (2017). A survey on the multi-device media usage of millennials. Journal of the Ergonomics Society of Korea, 36(6), 645663.

Lee. S. S. (2008). Gender differences in impulse buying: From the Perspective of materialism and cognitive need for closure. Korean Journal of Consumer and Advertising Psychology, 9(3), 475-495.

Mai, N. T. T., Jung, K., Kantz, G., \& Loeb, S. (2003). An exploratory investigation into impulse buying behavior in an transitional economy: A study of urban consumers in Vietnam. Journal of International Marketing, 11(2), 13-35.

McDougall, G. H., \& Levesque, T. (2000). Customer satisfaction with services: Putting perceived value into the equation. Journal of Services Marketing, 14(5), 392410.

Meyers-Levy, J. (1989). Gender Differences in Information Processing. In P. Cafferata, \& A. Tybout (Eds.), Cognitive and affective responses to advertising (pp. 219-260), MA: Lexington Books.

Myers, K. K., \& Sadaghiani, K. (2010). Millennials in the workplace: A communication perspective on millennials' organizational relationships and performance. Journal of Business and Psychology, 25(2), 225-238.

Ng, E. S., Schweitzer, L., \& Lyons, S. T. (2010). New generation, great expectations: A field study of the millennial generation. Journal of Business and Psychology, 25(2), 281-292.

Nielsen (2015). Global generational lifestyles: How we live, eat, play, work and save for our futures. Retrieved September 4, 2018 from http://www.nielsen.com/ content/dam/nielsenglobal/eu/docs/pdf/Global\%20Gener ational\%20Lifestyles\%20Report\%20FINAL.PDF.

Oh, S. Y., Kwon, Y. S., \& Lee, S. Y. (2014). Self-portrait of central government official: A Comparative study on the influence factors of organizational commitment among generations. Korean Public Personnel Administration Review, 13(1), 31-62.

Park, H. R. (2010). Internet purchase behavior based on anticipated emotion induced theory of planned behavior: Focused on gender difference. Korean Journal of Consumer and Advertising Psychology, 11(4), 661-686.

Park, K. S., Kim, J. B., \& Yang, H. C. (2015). Food and nutrition students' evaluation for home meal replacement quality using importance-performance analysis. Journal of Distribution Science, 13(7), 19-24.

Peter, J. P., \& Olson, J. C. (1999). Consumer behavior and marketing strategy. Boston: Irwin/ McGraw-Hill.

Powers, T. A., \& Zuroff, D. C. (1988). Interpersonal consequences of overt self-criticism: A comparison with neutral and self-enhancing presentations of self. Journal of Personality and Social Psychology, 54(6), 1054-1062.
Robertson, T. S. (1976). Low-commitment consumer behavior. Journal of Advertising Research, 16(2), 19-24.

Rook, D. W., \& Hoch, S. (1985). Consuming impulse. Advances in Consumer Research, 12, 23-27.

Rudman, L. A. (1998). Self-promotion as a risk factor for women: The costs and benefits of counter stereotypical impression management. Journal of Personality and Social Psychology, 74(3), 629-645.

Ryu, M. H., \& Lee, S. S. (2013). Undergraduate consumers' repurchase intention and recommendation intention depending on the safety satisfaction with ready-to-eat foods. Journal of Consumption Culture, 16(2), 91-115.

Schuman, H., \& Scott, J. (1989). Generations and collective memories. American Sociological Review, 54(3), 359381.

Shin, Y. H., \& Lee, K. Y. J. (2018). A study of brand communication through the consumer trend of the millennial generation and mirrors from a dualistic perspective. Journal of the Korean Society of Design Culture, 24(1), 355-364.

Sivadas E., \& Baker-Prewitt, J. L. (2000). An examination of the relationship between service quality, customer satisfaction, and store loyalty, International Journal of Retail \& Distribution Management, 28(2), 73-82.

Solomon, M. R., \& Rabolt, N. J. (2004). Consumer behavior in fashion. New Jersey: Pearson Education, Inc.

Stafford, D. E., \& Griffis, H. S. (2008). A review of millennial generation characteristics and military workforce implications. Center for Naval Analysis. Retrieve September 4, 2018 from http://citeseerx.ist.psu.edu/viewdoc/download?doi=10.1. $1.148 .7496 \&$ rep=rep $1 \&$ type $=$ pdf.

Stanley, T., \& Sewall, M. (1976). Image inputs to a probabilistic model: Predicting retail potential. Journal of Marketing, 40(3), 48-53.

Straus, W., \& Howe, N. (1991). Generations: The history of America's future. New York: Quill.

Tam, L. M. J. (2004). Customer satisfaction, service quality and perceived value: An integrative model. Journal of Marketing Management, 20(7-8), 897-917.

Taylor, P., \& Keeter, S. (2010). Millennials: A portrait of generation next, confident, connected, open to change. Washington D.C: Pew Research Center.

Traylor, M. B. (1981). Product involvement and brand commitment. Journal of Advertising Research, 21(6), 5156.

van Bommel, E., Edelman, D., \& Ungerman, K. (2014). Digitizing the consumer decision journey. McKinsey \& Company, June, 1-8.

Yang, H. C., \& Cho, H. Y. (2018). Effects of user-perceived important factors of social commerce on satisfaction and purchasing intention: Focusing on impulse buying. The Asian International Journal of Life Sciences, 15(3), 2059-2072.

Yang, H. C., Cho, H. Y., \& Kim, Y. E. (2017). Gap: A study on the influence of new measurement method on consumers' decision making. Journal of Distribution 
Science, 15(1), 51-56.

Yang, H. C., Choi, B. N., Lee, C. H., \& Kim, J. B. (2016). Effects of shopping orientation, trust and satisfaction on WOM intention: Focusing on undergraduates' HMR choices. International Journal of $u$ - and e-Service, Science and Technology, 9(4), 175-184.

Yang, H. C., Hur, M. Y., \& Yang, W. R. (2018). GAP: A study on strategic derivation approach using perceptual difference. International Journal of Industrial Distribution \& Business, 9(2), 17-26.

Yang, H. C., Kwon, W. T., \& Kim, D. H. (2014). An IPA- based study on potential for the continued development of sextic industry from the producers' viewpoint. Journal of Distribution Science, 12(11), 15-23.

Yoon, H. H., Kim, J. S., \& Oh, J. K. (2012). Principle of marketing. Seoul: Chongmok Publishing Co.

Zeithaml, V. A. (1988). Consumer perceptions of price, quality and value: Means-end model and synthesis of evidence. Journal of Marketing, 52(3), 2-22.

Zickuhr, K. (2011). Generations and their gadgets. Washington, DC: Pew Internet \& American Life Project. 